\title{
Enacting Promissory Estoppel into the Malaysian Law: Towards More Certainty in Litigation
}

\author{
Wan Izatul Asma Wan Talaat ${ }^{1}$ \\ ${ }^{1}$ Faculty of Management \& Economics and Institute of Oceanography and Environment, Universiti Malaysia \\ Terengganu, Malaysia \\ Correspondence: Wan Izatul Asma Wan Talaat, Faculty of Management \& Economics, Universiti Malaysia \\ Terengganu, 21030 Kuala Terengganu, Malaysia. Tel: 609-668-4273/6019-9363808. Fax: 609-6684285. E-mail: \\ wia@umt.edu.my
}

Received: Feburary 27, 2012 Accepted: March 5, 2012 Online Published: April 26, 2012

doi:10.5539/jpl.v5n2p19

URL: http://dx.doi.org/10.5539/jpl.v5n2p19

\begin{abstract}
Promissory estoppel is an equitable principle meant to prevent any occurrence of inequity or injustice caused by the action of the promisor in backing out from his promise, which initially led the promisee to act to his detriment. This paper discusses the proposal to statutorily enact promissory estoppel into the Malaysian laws, which is based on three reasons: (i) to clearly define its parameters for the easier application by the courts because now that unconscionability is being the main focus in granting promissory estoppel, in lieu of detrimental reliance, the thin line surrounding its parameters are becoming more vague; (ii) to undo its limited interpretation and application as an equitable doctrine that is subject to numerous rules of equity, which may potentially arrest the development of equity and compromise the administration of justice; and (iii) to avoid the statutory restriction imposed by Section 3(1) of the Civil Law Act 1956, which necessitates the reception of this equitable doctrine to be subject to the exclusionary phrase stated in the beginning of Section 3(1) denoting that its application of promissory estoppel in Malaysia can only be carried out only when there is a lacuna in such area of law.
\end{abstract}

Keywords: statutory enactment, promissory estoppel, malaysian law

\section{Introduction}

Promissory estoppel is an equitable principle meant to prevent any occurrence of inequity or injustice caused by the action of the promisor in backing out from his promise, which had initially led the promisee to act to his detriment. The origin and meaning of this doctrine was judicially explained by Lord Cairns in Hughes $\mathrm{v}$ Metropolitan Railway Co. (1877) 2 AC 439, at page 498, as follows,

“...It's the first principle upon which all courts of equity proceed, that if parties who have entered into definite and distinct terms involving certain legal results - certain penalties or legal forfeiture - afterwards by their consent enter upon a course of negotiation which has the effect of leading one of the parties to suppose that the strict rights arising under the contract will not be enforced, or will be kept in suspense, or held in abeyance, the person who otherwise might have enforced those rights will not be allowed to enforce them where it would be inequitable having regard to the dealing which has thus taken place between the parties.”

This definition of what amounts to promissory estoppel has in fact been referred to in many later cases. According to Oxford, estoppel is a rule of evidence or a rule of law, which prevents a person from denying the truth of a statement he has made or from denying facts that he has alleged to exist (Martin, 1986). Such fact must be one that the other person, to whom the statement is made, has relied and acted upon or the one that has caused him to alter his position. In Simm v Anglo American Telegraph Co (1879) 5 QBD 188, Bramwell LJ tentatively suggested at page 203 that estoppel may exist where a person is compelled to admit something that is not true as well as to act upon a theory contrary to the truth. From all the above attempts to describe promissory estoppel, it can be said that promissory estoppel, which falls under the category of estoppel by representation, is applicable when one party to a contract promises the other, either by words or conduct, that he will not enforce his right under the contract wholly or partially. If the other party has acted in reliance of that promise, the person making the promise will be bound by it and pursuant to that, he will not be allowed to sue on the contract. 
Traditionally, as an equitable doctrine, the scope of the doctrine of promissory estoppel is limited in many senses, which actually helped to draw its parameters. There are five traditional limitations of promissory estoppel namely:-

i. Promissory estoppel as a sword, which restricts the application of this doctrine to as far as only to provide a defence to a party and not to be used as a cause of action against another.

ii. Pre-existing contractual relationship, which restricts the application of this doctrine to cases between the contracting parties, which means that there must be a legally binding contract before promissory estoppel can be invoked.

iii. Clear and unequivocal undertaking where the promise or representation must be "precise" and "unambiguous" although it does not mean that such promise or representation must be expressly made.

iv. Detrimental reliance on the representation, which requires proof of possible detriment or prejudice, which will materialise if the promisor is allowed to go back to his original promise.

v. Temporary suspension of contractual obligations and rights, which operates in the sense that the doctrine applies to representations relating to past and present events only by excluding the future events (executory promise).

The above limitations had previously helped to clearly outline its parameters. Nevertheless, the position of promissory estoppel now, as proclaimed by Lord Denning (1982), is shorn by limitations. The doctrine is presently being applied more flexibly than the time when it was first promulgated in 1887 through the Hughes case in 1877 and complemented through the High Trees case in 1947 (Wan Izatul, 2003). Now that unconscionability is being the main focus in granting promissory estoppel, in lieu of detrimental reliance, it seems that the courts in the common law countries i.e. England, Australia and Malaysia are more than willing to do as equity demands. In India, this doctrine has also undergone rapid development as can be seen in the case of Motilal Padam Sugar Mills Co Ltd v The State of Uttar Pradash AIR 1979621 and Delhi Cloth \& General Mills Ltd v Union of India AIR 1987 SC 2414. The following words of Gopal Sri Ram JCA in the Malaysian landmark Boustead Trading (1985) Sdn Bhd v Arab-Malaysian Merchant Bank Bhd [1995] 3 MLJ 331, at page 344, is a clear indication of how promissory estoppel is being treated by the courts,

"The time has come for this court to recognise that the doctrine of estoppel is a flexible principle by which justice is done according to the circumstances of the case. It is a doctrine of wide utility and has been resorted to in varying fact patterns to achieve justice. Indeed, the circumstances in which the doctrine may operate are endless."

The continuing development of promissory estoppel in the common law countries has definitely been affecting the present parameters of this doctrine and thereafter dimming the thin line surrounding its limitations. With the negation of the requirement of pre-existing relationship, the application of this doctrine can now extend to gratuitous promise and go beyond the scope of contract law, which is the original domain of promissory estoppels. This phenomenon consequentially affects the significance of the doctrine of accord and satisfaction and certainty that stand amongst the elements of a valid contract. Similarly, when this doctrine operates to permanently estop a representee from exercising his contractual rights, it would relatively create a redundancy in countries like Malaysia where waiver, which has a permanent effect, has been provided for under Section 64 of its Contracts Act 1950.

Nevertheless, this development does have its bright side. Now that promissory estoppel is made available to a plaintiff, its objective of providing justice can be further extended to all contracting parties. A promisee, who has suffered from acting upon a promise, can now seek redress from the court rather than wait until a claim is filed against him. The positive effect brought by the development of this doctrine can also be found by the recognition given to the newer notion of unconscionability in place of the requirement of proof of detrimental reliance on the part of the promise thereby giving more room to justice and fairness in dealings. Needless to say, the side line and moderate view manifested by some English and Malaysian judges, whose preference are "fairness", "justice" and "equitability", may be seen as providing a check and balance to the development of this doctrine.

\section{Statutory Enactment of Promissory Estoppel into the Malaysian Law}

Promissory estoppel, which is an English doctrine of equity, has been widely accepted throughout the common law countries through the colonisation by the British Empire. In the United States, this equitable doctrine has been enacted as a statutory provision under Article 90 of the Second Restatement of Contract thereby facilitates its easier application by the courts. Article 90 provides for promissory estoppel as follows, 
"A promise which the promisor should reasonably expect to induce action or forbearance of a definite and substantial character on the part of the promise and which does not induce such action or forbearance in binding if injustice can be avoided only by enforcement of the promise."

The quest for the statutory enactment of promissory estoppel into the Malaysian statutory regime may be considered as a constructive and beneficial contribution of this study to the development of the Malaysian law. Actions taken by its American counterpart in enacting promissory estoppel into their Article 90 of the Second Restatement of Contract may positive effects if Malaysia were to follow such footsteps. The positive effects of incorporating this equitable doctrine into the Malaysian statute law are twofold; firstly, it would help to clearly define the parameters of this doctrine, which would lead to more certainty in litigation and secondly, its statutory enactment would certainly facilitate its application by the Malaysian courts, which will no longer be bound by the restrictive rules of equity and the statutory restrictions imposed by Section 3(1) of the Civil Law Act 1956.

There are three underlying reasons for the statutory incorporation of this equitable doctrine. Firstly, the continuing evolution of promissory estoppel in the common law countries especially in England, Australia and Malaysia has led the unclear parameters of this doctrine. By incorporating promissory estoppel into a statutory form, the parameters of this doctrine will inadvertently be clearly defined, which will eventually lead to more certainty in litigation and facilitate its application by the Malaysian courts. The second reason that calls for the incorporation of this doctrine is the fact that as an equitable doctrine, promissory estoppel is relatively a restricted as well as limited doctrine. The interpretation and application of this doctrine is undoubtedly subject to numerous rules of equity that may include the maxims "delay defeats equity", "he who comes to equity must come with clean hands", "where there is equal equity, the law shall prevail”, "equity follows the law" and many others. Being an equitable doctrine, promissory estoppel cannot be freely interpreted and applied by the Malaysian courts, as compared to a domestic statutory provision. Although the attempts by the common law courts have hinted the inclination of these courts to loosen up from the rigid requirements of the equitable rules, the fact remains that promissory estoppel has always been an equitable doctrine, which renders the application of this doctrine in Malaysia as very restrictive. The difficulty of applying promissory estoppel is also aggravated by the fact raised by Loughlan (1990), who describes equitable remedies as discretionary, which is not compelled upon the courts to grant. The difficulty and restrictiveness in applying an equitable doctrine can also be seen from the view put forward by Nast (2002) that in a mingling between an equitable doctrine and common law, two difficulties may crop up i.e.:

i. Unfairness to litigants because the principles and application of equity would be unclear;

ii. The decrease in the use of equity by the judiciary, which may potentially arrest the development of equity and compromise the administration of justice.

The third reason, which calls for the statutory incorporation of this doctrine, is connected to the reception of promissory estoppel into the Malaysian law due to the statutory restrictions imposed by Section 3(1) of the Civil Law Act 1956. Since the application of this doctrine in Malaysia is capacitated through this provision the reception of this doctrine as a rule of equity is subject to the exclusionary phrase stated in the beginning of Section 3(1) that reads ... "Save so far as other provision has been made or may hereafter be made by any written law in force in Malaysia...". Such connotation denotes that the application of promissory estoppel in Malaysia can only be carried out only when there is a lacuna in such area of law in Malaysia. This fact is reiterated by Teo \& Khaw (1991), who explicitly view that the provision of Section 3 will only allow the general reception of English equity only in situation when there is a lacuna in the local law and where it is suitable to local circumstances. The question of whether there exists a lacuna that necessitates the reception of promissory estoppel in Malaysia leads to an existing "similar" provision in the Malaysian Contracts Act 1950, where its Section 64 readily provides for statutory waiver that signifies a similar effect to promissory estoppel at least where a contract is involved.

Other than the above general prohibition, it must also be noted that Section 3(1) also imposes restrictions under its proviso, which specifically confines the application of promissory estoppel to so far only as the circumstances of the States of Malaysia and their respective inhabitants permit and subject to such qualifications as local circumstances render necessary. This point was also pointed out by Abdul Hamid Mohamed J, who suggested in Bencon Development Sdn Bhd v Yeoh Cheng Heng [1996] 4 CLJ 25 that, instead of "blindly" following the path initiated in the Boustead's case, the courts should treat the application of this doctrine objectively. His Lordship lamented that since the introduction of equitable estoppel, the courts have begun to apply the doctrine without considering the provisions of Section 3 of the Civil Law Act 1954 especially its proviso. A very profound note on this matter was made at page 31 as follows, 
"I do not say the introduction of the principle is not for the better. ... One wonders what would have been the result if the provision of s. 3 of the Civil Law Act 1956 was considered. ...With the introduction of the principle of equitable estoppel plus rapid development in the country the situation has changed. Demands are made by the occupiers, some time very unreasonable ones....”

This phenomenon has certainly resulted "to a dearth of local authorities on the principles to be applied or the factors to be considered in deciding how equity is to be satisfied." It may be safe to infer that His Lordship was trying to criticise the enthusiasm of the Malaysian courts to develop equitable estoppel by following the steps of its common law brothers rather than applying this doctrine subject to the provision of Section 3(1) of the Civil Law Act 1954, which may eventually lead to an unruly situation. Collectively, both the general provision of Section 3(1) of the Civil Law Act 1956 and its proviso, by taking into account of Section 64 of the Contracts Act 1950, explicitly restrict the application of promissory estoppel in the following manner: -

( $i$ )When there is no written law in Malaysia, which are already in existence, to the same effect;

(ii When the circumstances of the States of Malaysia and their respective inhabitants permit; and

(iii)As local circumstances render necessary.

It is thus safe to assert that the phenomenon due to the continuing evolution of promissory estoppel, which seems to affect its present parameters, and the existence of the above restrictions has called for the incorporation of promissory estoppel into the existing Malaysian legislations. The proposed statutory incorporation of this equitable doctrine into the Malaysian legislations would be much welcomed due to its potential of leading to more certainty in litigation. Once promissory estoppel is enacted, its parameters will be clearly defined. Furthermore, its application as a statute law would be able to facilitate those in the legal fraternity after no longer being subject to the restrictions as an equitable doctrine. A strong proponent of the incorporation of English common law and equity into the Malaysian law is His Royal Highness Sultan Azlan Shah, the former Lord President of Malaysia, who observes that there should no longer be reliance on English law as has been capacitated by the provisions of the Civil Law Act 1956 because throughout the years of applying these laws, which went through modifications and adoptions to suit local conditions, they have become Malaysian common law. Although His Highness does not explicitly suggest that such common laws and equitable principles be incorporated as statutory laws, his intention is well manifested from the fact that the Malaysian legal regime consists mainly of statutes that provide easier and practical mode of application to the courts.

\section{Existing Statutory Provisions Incorporating Equitable Doctrines}

For the purpose of realising the objective of enacting promissory estoppel into a statutory provision, a search was made into some relevant commercial-related statutes in England, Australia and Malaysia in order to reveal any existing statutory provision that incorporates any equitable doctrines or notions resembling promissory estoppel. Being an equitable doctrine, which application is subject to many restrictions, the prospect of enacting promissory estoppel is very much anticipated to benefit the process of administration of justice. Judging from the roles acquired by this equitable doctrine pursuant to its continuing evolution, one must have guessed its potential not only in the realm of equity but also in the overall justice system. There are 10 existing statutes in England, Australia and Malaysia that have been found to have been previously incorporated with this equitable estoppel or its resemblance.

\subsection{Section 21(1) of the English Sale of Goods Act 1979}

This section provides that a buyer who buys goods from a person, who is neither the owner of the goods nor an agent of the owner, acquires no title to the goods unless the owner of the goods is precluded by his conduct from denying the seller's authority to sell. This provision precludes the owner of goods from denying the seller's authority to sell and to transfer good title to a bona fide buyer, who buys goods from a person, who actually has no authority to sell, if his conduct indicates otherwise. Although the word "estopped" is eclipsed by the word "precluded" under this provision, it would reasonably be safe to infer that the intention of the legislators was to mean that the owner is estopped, based on his conduct, from claiming that the seller had sold the goods without his authority. For the purpose of illustration, the New Zealand case of N.Z. Securities \& Finance Ltd v Wrightcars Ltd [1925] 1 NZLR 77 may be highlighted where the owner was precluded or estopped from denying the seller's authority to sell to a third party. The plaintiff in this case sued the defendant for conversion by relying on the New Zealand equivalent of Section 21. The defendant sold a car to A, who was given possession of the car upon the tender of a cheque as payment. Although it was agreed that the property in the car was not to pass until the price has been received i.e. after the cheque has been cleared, A sold the car to the plaintiff and took it back on lease. Before the sale to the plaintiff was finalised, the plaintiff made a query to the defendant's office 
and was informed by the defendant's employee that A had paid for the car. Subsequently, the cheque tendered by A was dishonoured prompted the defendant to repossess the car. Upon knowing of such, the plaintiff successfully claimed against the defendant contending that the defendant was precluded, based upon the representation by its employee, from denying A's authority to sell the car and therefore, the title in the car had passed to the plaintiff.

\subsection{Section 2(1) of the English Factors Act 1993}

Under the Act governing the law relating to mercantile agents who, according to the customary course of business, has authority either to sell or consign goods for the purpose of sale, or to buy goods, or to raise money on the security of goods, This section provides for the validity of the disposition of goods made by a mercantile agent, who holds the goods or documents of title to the goods with the owner's consent, to any third party, who acts in good faith and has no notice that the person making the disposition has no authority to do so. It must be noted that this provision is verbatim to the proviso of Section 27(1) of the Malaysian Sale of Goods Act 1957 that reads,

“...where a mercantile agent is, with the consent of the owner, in possession of the goods or of a document of title to the goods, any sale made by him when acting in the ordinary course of business of a mercantile agent shall be as valid as if he were expressly authorised by the owner of the goods to make the same; provided that the buyer acts in good faith and has not at the time of the contract of sale notice that the seller has no authority to sell."

This section provides for the validity of the disposal of goods made by a mercantile agent, who holds goods or documents of title to such goods with the owner's consent, to any third party, who acts in good faith and has no notice that the person making the disposition has no authority to do so.

\subsection{Section 2(2) of the English Factors Act 1993}

This section provides for the validity of the disposal of goods by a mercantile agent, who holds goods or documents of title to such goods with the owner's consent that has subsequently been terminated, to any third party acting in good faith and has no notice of such termination.

\subsection{Section 51AA of the Australian Trade Practices Act 1974}

This provision extends the remedies available under the Act to unconscionable conduct within the meaning of unwritten law since the concept has now been accepted as part of the equitable principles as well as common laws recognised by the Australian courts. Sub-section (1) reads,

"A corporation must not, in trade or commerce, engage in conduct that is unconscionable within the meaning of the unwritten law, from time to time, of the States and Territories."

It has been said that the introduction of this provision was not to impose a new head of consumer protection law into this statute but to extend the remedies under the Trade Practices Act to unconscionable conduct to the extent that this notion has now formed part of the common law or equitable principles recognised by the court (Miller, 1996). The overlapping between the notion of unconscionability and promissory estoppel in Australia has always been around, especially since this notion has generally been accepted as the determining factor, instead of detrimental reliance, in promissory estoppel. The Amadio case (Commercial Bank of Australia Ltd v Amadio (1983) 151 CLR 447), which was considered as one of the cases that gave rise to the introduction of Section 51AA, is a great example of how these two equitable principles may work together. In this case, where the High Court refused to allow the bank's claim to enforce the guarantee given by the Amadios in security for their son's loan, the vitiating factor that was taken into account was unconscionability. Mason J reasoned the High Court's finding at page 461 as follows,

"Relief on the ground of unconscionable conduct will be granted when unconscientious advantage is taken of an innocent party whose will is overborne so that it is not independent and voluntary, just as it will be granted when such advantage is taken of an innocent party who, though not deprived of an independent and voluntary will, is unable to make a worthwhile judgment as to what is in his best interest."

Before reaching to the decision that it would be unconscionable for the bank to enforce the guarantee, the court had in fact looked into the following material facts; that the Amadios' grasp of English was poor; that they did not seek independent legal advice and no suggestion to do so was made by the bank; that the bank knew of the son's financial condition, which was not known to the Amadios; and that the bank did not advise the Amadios of their unlimited liability under the guarantee.

Another Australian case that was considered as to have inspired the promulgation of Section 51AA, which was already decided almost three decades prior to the Amadio case, i.e. Blomley v Ryan (1956) 99 CLR 362 where 
the High Court refused the plaintiff's claim for specific performance, or damages, in respect of a contract for the purchase of a rural property in Queensland on the ground of unconscionability. The court had in fact taken into consideration of the defendant's allegations; that at the time of the contract, he was "an old man, lacking in education, suffering from the effect of intoxication, mentally and physically weak, without proper advice, unable to protect himself and on unequal terms with the plaintiff" and; also the fact that the contract price was only for AUD25,000 i.e. AUD8,000 less than the market value, before deciding that the contract was a thoroughly unconscionable transaction. The following words of Kitto $\mathrm{J}$ at page 415 may, inter alia, be safely considered as the origin of the term "unwritten law" under Section 51AA, which reads as follows,

"[The court has power to set aside a transaction]...whenever a party to a transaction is at a special disadvantage in dealing with the other party because of illness, ignorance, inexperience, impaired faculties, financial need or other circumstances affecting his ability to conserve his own interests, and the other party unconscientiously takes advantage of the opportunity thus placed in his hands."

It is important to note that the incorporation of unconscionability into the Trade Practices Act 1974 has been shadowed with the overwhelming needs to protect unfairness and injustice to the Australians when dealing with traders. The Second Reading speech on 3 November 1992 when the legislation was introduced reads as follows,

"Unconscionability is a well understood equitable doctrine, the meaning of which has been discussed by the High Court in recent times. It involves a party who suffers from some special disability or is placed in some special situation of disadvantage and an 'unconscionable' taking advantage of that disability or disadvantage by another. The doctrine does not apply simply because one party has made a poor bargain. In the vast majority of commercial transactions neither party would be likely to be in a position of special disability or special disadvantage, and no question of unconscionable conduct would arise. Nevertheless, unconscionable conduct can occur in commercial transactions and there is no reason why the Trade Practices Act should not recognise this.” The insertion of this recent provision into the trade Practices Act was intended to facilitate the application of this doctrine and to provide a clearer path for persons, who have been unconscientiously been taken advantage of in commercial dealings, to seek redress from the court.

\subsection{Section 52 of the Australian Trade Practices Act 1974}

This provision proscribes a corporation from engaging, whether in trade or commerce, in conduct that is misleading or deceptive or is likely to mislead or deceive. This provision provides a general prohibition against misleading or deceptive conduct in commercial activities. The predominant task held by this provision is one of the most heavily litigated statutory provisions in Australian Law, the interpretation given by the Australian Courts to this provision extends beyond consumer protection that makes it an extremely important consideration for contracting parties although it being located in the part of the Trade Practices Act, 1974 titled "Consumer Protection" (Seah, 2001). After the Walton Stores case, both Section 52 and promissory estoppel are potentially affecting every aspect of contract law as well other commercial relations where there exists no contract (Seddon, 2001).

In Lee Gleeson Pty Ltd v Sterling Estates Pty Ltd (1991) 23 NSWLR 571, which has been discussed in great detail under the preceding chapter, the issue of promissory estoppel was dealt along with Section 52. The alternate use between this equitable doctrine and this written provision can be clearly seen when Brownie J, at the Supreme Court of New South Wales, held inter alia that:-

i. Under Section 52 of the Trade Practices Act 1974, the second defendant bank was found to be liable for misleading and deceptive conduct. It was explained that in cases where a bank informed a third party that it had been authorised to make payment on behalf of its customer and such instruction had subsequently been countermanded, it was under duty to inform the third party of the change. The failure by the bank to inform such change would then amount to "misleading and deceptive conduct" under the Act;

ii. Under promissory estoppel, the second defendant bank was estopped from subsequently denying the existence or the binding quality of its representation on the ground of the bank's assurance, upon reference by the plaintiff, that it would be paid for the work before promising to complete work within a prescribed time. It was reasoned that it would seem unconscionable for the bank to resile from its promise to the plaintiff, which had led the plaintiff to execute the deed on 24 April 1990.

The above treatment of promissory estoppel as an equivalent to Section 52 may safely be taken as a hidden similarity between these two allied notions, which has in fact been previously hinted where the provision of Section 52 had always been treated and invoked in light and along with this equitable doctrine. 


\subsection{Section 3(1) and 4 of the Malaysian Partnership Act 1961}

Although Section 3(1) only provides for the definition of "partnership", which is "the relation which subsists between persons carrying on a business in common with a view in profit", it is important to note that its construction by the court is extremely important especially when it is raised along with Section 4, which speaks on circumstances not prima facie partnership. This issue was examined with great detail in Aw Yong Wai Choo v Arief Trading Sdn Bhd \& Anor [1992] 1 MLJ 166, where the court was asked to determine, inter alia, whether the second defendant was a partner with the first defendant. In this case, the defendants entered into an agreement to develop a land, which was leased to the second defendant by the Perak State Government, into a housing scheme. Under the agreement, which was alleged by the plaintiffs as a joint venture between the defendants, it was stated that the first defendant was to develop the land and the second defendant was to obtain $50 \%$ of the profit as consideration for the licence to such development. The first defendant, vide some sale and purchase agreements, agreed to build houses and sell them to the plaintiffs within a stipulated time. The construction of the houses did not even start after the expiry of the stipulated time causing $\mathrm{X}$, one of the purchasers, to commence the first action and obtain a summary judgment against the defendants. The second defendant then filed an appeal, which was subsequently withdrawn following a settlement with $\mathrm{X}$ whereby the second defendant offered to build the houses with a 50\% increase in the purchase price or alternatively to pay an ex-gratia payment without admission of liability. $\mathrm{X}$ and other purchasers agreed to the settlement but the plaintiffs rejected by claiming from the defendants for the specific performance of the sale and purchase agreements and liquidated damages for late delivery of the houses. The second defendant proceeded to build the houses by employing new and more expensive specifications. At the hearing of this action, the plaintiffs alleged that the second defendant was a partner to the first defendant on the ground that the brochure distributed to potential house buyers and the sign board at the work side had both indicated that the housing estate was a joint venture between the defendants. It was held by the court that in order to find a partnership as defined under Section 3(1) of the Partnership Act 1961, the court must find the real intention of the parties and for such purpose, the rules for determining the existence or inexistence of a partnership under Section 4 cannot be exhaustive.

It was further viewed that the provision of 50\% profit for the second defendant under the agreement between the defendants gave rise to a refutable presumption of the fact that a partnership existed between them and it was concluded on this issue that, on the balance of probabilities, the indicia of partnership outweighed the negative factors and the second defendant was rightfully been sued as the partner to the first defendant. This case may serve as an indication of the court's readiness to construe the provision of Section 3(1) of the Partnership Act as a means to estop a person, who has fulfilled the criterion as a partner under the provision i.e. someone who has a relation with the partner of the firm by "carrying on a business in common with a view of profit" as well as someone who has led another, by his conduct, to believe that he is partner to a particular firm, from claiming otherwise.

\subsection{Section 7 of the Malaysian Partnership Act 1961}

This provision relates to power of partner to bind firm where every partner is considered as an agent of the firm as well as of his other partners for the purpose of the partnership's business. This section is closely related to the law of agency, whose existence is created by partnership. The provision clearly reads,

"Every partner is an agent of the firm and his other partners for the purpose of the business of the partnership, and the acts of every partner who does any act for carrying on in the usual way business of the kind carried on by the firm of which he is a member bind the firm and his partners, unless the partner so acting has in fact no authority to act for the firm in the particular matter, and the person with whom he is dealing either knows that he has no authority or does not know or belief him to be a partner."

This section provides for the power of partner to bind firm where every partner is considered as an agent of a particular firm and the other partners of the firm for the purpose of the partnership's business. Thus, an act that is done by a partner "in the usual way the business" of the kind carried on by the firm shall bind the firm and his partners. Nevertheless, if the said partner acts without any authority and the person he is dealing with either knows that he has no authority or does not know or believe him to be a partner, the act shall no longer bind the firm and his other partners. The question of what constitutes an act done in "the usual way of business" is best explained by Kuala Lumpur High Court in Chang Kin Yue v Lee \& Wong [1962] 1 MLJ 379 where Suffian J [as he then was] proclaimed that the borrowing of RM35,000, by the plaintiff's husband from her as loan to a partnership of which he was a partner, was an act "necessary for the carrying out of business" under Section 204 of the Contracts (Malay States) Ordinance 1950, which was the equivalent provision to the present Section 7 of the Partnership Act 1961. 
It was further found from the following facts, that the plaintiff's husband had issued her a receipt of the loan in the partnership's name and that the money was subsequently paid in the firm's account and was immediately thereafter utilised to pay off the firm's debt, had entitled the plaintiff "in equity" to stand in the same position as if the money had originally been borrowed by the partnership. Although no words of "estoppel" or "preclusion" was mentioned anywhere in the judgment, it must be noted that the court's finding that the plaintiff was held as entitled "in equity" to stand in the same position as if the money had originally been borrowed by the partnership and that the act of borrowing by the plaintiff's husband were to bind the firm may safely be inferred to indicate the court's intention to treat the firm, as well as the other partners, as estopped or precluded from denying that the plaintiff's husband had acted with an authority to do so. By taking into account all the above relevant facts involving the conducts of the plaintiff's husband and the firm, clear inference can be made from the court's decision that it must have intended to preclude the firm from denying liability. The fact that the firm utilised the money to pay off its debt is vividly a "conduct" that must be accepted as an act falling under the qualification to equitable estoppel or estoppel by conduct.

\subsection{Section 16 of the Malaysian Partnership Act 1961}

This provision imposes liability on a person who holds out, either by spoken or written words or conduct, or knowingly lets himself to be represented as a partner of a particular firm, to the representee, who has given credit to the firm on the faith of that representation. This provision on the principle of "holding out", which comes under Part III of the Partnership Act providing for relations of partners to persons dealing with them, clearly provides that,

"Every person who by words spoken or written or by conduct represents himself, or who knowingly suffers himself, to be represented, as a partner in a particular firm is liable as a partner to any one who has on the faith of any such representation given credit to the firm, whether the representation has or has not been made or communicated to the person so giving credit by or with the knowledge of the apparent partner making the representation or suffering it to be made."

Under this principle of "holding out", if a person holds out himself or let himself to be represented as a partner to a particular firm, he is made liable to the representee, who has acted upon such representation by giving credit to the firm. Correspondingly, under the equitable doctrine of promissory estoppel, a person is bound by his representation, either by words or conduct, which has led another to act according to such representation. One clear application of this principle of holding out is the Singaporean case of Wong Peng Yuen v Senanayake [1962] MLJ 204. The plaintiff's claim for the return of $\$ \$ 20,000$ upon notice for the dissolution of the partnership firm, on the ground that he was never a partner of the firm, was rejected after the court took into account his acts of paying the said sum as consideration of him being made a partner and consequently thought and acted as if he was a partner. Thus, the act of the plaintiff acting as a partner of the firm after paying the sum of $S \$ 20,000$, despite him being inactive in the management and control of the firm, was found as sufficient to hold him liable on the principle of holding out.

Initially, under the traditional requirement of promissory estoppel that requires the pre-existing contractual relationship between the parties, this principle of holding out cannot be equated with promissory estoppel because a person is said as to have "hold out" after he had led a third party into dealing with the partnership, which means that there is no pre-existing contractual relationship between the parties. However, due to the continuing evolution of this doctrine that has negated the pre-requisite of contractual relationship thus making this doctrine available to any kind of legal relationship, the only difference between these two principles has now been breached. It can be safely concluded from the above case that the principle of holding out under Section 16 of the Partnership Act does operate in a similar way as an equitable estoppel. When a person holds out as a partner to a particular firm leading a third party to act according to his "representation", this provision operates to "estop" him from claiming otherwise.

\subsection{Section 38(1) of the Malaysian Partnership Act 1961}

This provision confers the right to a third party, who deals with a firm after the change of its constitution without having been notified of such change, to still treat all apparent members of the old firm as the firm's partners until he has notice of such change. This section expressly provides as follows,

"Where a person deals with a firm after the change in its constitution, he is entitled to treat all apparent members of the old firm as being members of the firm until he has notice of the change."

The principle embedded under this provision is more commonly known as apparent or ostensible authority. Under this provision, if the remaining partners to a firm fail to notify the public of the retirement of a particular 
partner, who continues to act as one, they will be "estopped" from denying his acts on the principle of apparent authority (Vohrah and Wu, 2000). Similarly, a retired partner, who has failed to "notify" the public of his retirement shall remain liable for the partnership's debt under this principle. What is a sufficient notice of withdrawal of a partner to any person dealing with a particular partnership is best explained in the case of Re Chop Yew Seong; Ex parte Sri Sundari Palayakat Co [1958] MLJ 239 where it was decided to the effect that,

"When a known partner retires, or a partnership is dissolved, notice of the fact must be given to the world at large by advertisement, and to old customers by special communication. An old customer is entitled to a more specific notice than a person who never dealt with the firm at all; and in considering whether notice of dissolution or retirement is or is not sufficient, a distinction must be made according as the person sought to be affected by notice was or was not a customer of the old firm. A mere notice to the Registrar of Business Names is not sufficient.”

A clear illustration of the application of this provision can subsequently be seen in Hup Aik Tin Mining Company v Kam Hoy Trading [1969] 1 MLJ 93, where an appeal against the dismissal of the defendant's application to set aside the service of the writ of summons and notice was dismissed by the Federal Court. The plaintiffs claimed for the sum of $\$ 4,425.70$ being balance owed by the defendants to the plaintiffs for the supply of diesoline and other lubricants from July 1965 to October 1965. The writ of summons and notice were served on all the three partners of the defendant firm as shown by the Registry of Business. They alleged that they had ceased to be partners during the said period after having sold and assigned all their shares to Pang Sang, who obviously did not send in the withdrawal forms signed by them for registration. The Federal Court held that a person who has habitual dealings with a partnership, as the plaintiffs were in this case, is entitled to be specifically notified of the withdrawal of the partners and a mere notice to the Registrar of Business is insufficient. Thus, the service of the writ of summons and notice on the persons whose names appear in the register as partners was to be considered as good service. Barakbah LP declared that regardless of whether the withdrawal forms were received by the Registrar, as persons having habitual business with the partnership, "the plaintiffs should have been given notice of the withdrawal by the defendants....”

\subsection{Section 27(1) of the Malaysian Sale of Goods Act 1957}

An equivalent provision to the present English provision of Section 21(1), this section expressly provides that,

"Subject to this Act and of any other law for the time being in force, where goods are sold by a person who is not the owner thereof, and who does not sell them under the authority or with the consent of the owner, the buyer acquires no better title to the goods than the seller had, unless the owner of the goods is by his conduct precluded from denying the seller's authority to sell."

Under this provision, the owner of goods is "precluded" from denying the seller's authority if he, by his conduct, makes it appear to the buyer that the person selling the goods has his authority to do so and the buyer consequently acts in reliance upon such conduct. A buyer who buys goods in good faith is conferred with a good title in the goods sold by a person who is neither the owner of the goods nor his agent. In spite of the absence of the word "estop" in this provision, it must be admitted that the word "precluded" must be taken as to give an equivalent effect of an estoppel. This was discussed in the New Zealand's case of N.Z. Securities \& Finance Ltd v Wrightcars Ltd [1925] 1 NZLR 77, which has been thoroughly quoted under the English equivalent to this provision.

\section{Conclusion}

From the above discussion, there is no provision in England that has specific resemblance to promissory estoppel or any other types of equitable estoppels except Section 21(1) of the Sale of Goods Act 1979, which may be considered as a minuscule effort taken by the English Parliament in the overall attempt to facilitate the application of equitable doctrines. Nevertheless, it may also be reasoned that there was no such need to enact equitable doctrines in England because, unlike the position in Malaysia, the application of equitable as well as common law doctrines are not subject to the two restrictions mentioned beforehand. On the other hand, the statutory regime in Australia puts great emphasis on the prohibition of conduct that is unconscionable, misleading and deceptive by giving remedial provisions to contracting parties especially those involving consumers. The above provisions, especially Section 52 of the Trade Practices Act 1974, clearly proscribe actions that would transgress the rights of contracting parties by prohibiting misleading and deceptive conduct. The word "conduct" may include actions and words, either through promises, predictions or opinions. When a person makes a promise that leads another to act upon such promise, equitable estoppel may step in and the person, by the standard set by the present parameters of this doctrine, is likely to be bound by his words. 
This is what the Australian statutory regime is trying to pull off - to give an alternative route for a wronged party rather than resort to the traditional actions based on contract and torts. In spite of the rapid growth of promissory estoppel in this country, there has been no direct attempt to enact this equitable doctrine into a statutory form so as to regulate and facilitate its application. Nonetheless, at this juncture, it must not be dismissed that there has been at least one attempt taken by the Australian Parliament to pay tribute to this equitable doctrine through the provision of Section 51AA, which was introduced in 1998 into the Trade Practices Act 1974 following the trends of the courts in recognising the notion of unconscionability in unwritten laws, especially equity, in Australia. However, due to the absence of any statutory definition on the term "unconscionability", the Australian courts are then left with the heavy task of determining what conduct can be correctly interpreted as unconscionable, which can be clearly seen in Berbatis Holdings case [2003] HCA 18. In Malaysia, there have been many equitable doctrines previously enacted as statutory provisions. One clear instance is the Limitation Act 1953 that prohibits delay in action and arbitration, which is in line with the equitable maxim "delay defeats equity" or the more universally known equitable doctrine of laches. In addition to that, there are also other instances of statutory provisions that either incorporate or contain resemblance to promissory estoppel or other types of equitable estoppels as discussed above.

As an English doctrine of equity, promissory estoppels has been widely accepted throughout the common law countries through the colonisation by the British Empire. In the United States, this equitable doctrine has been enacted as a statutory provision under Article 90 of the Second Restatement of Contract, which has subsequently facilitated its easier application by the courts. The quest for the statutory enactment of promissory estoppel into the Malaysian statutory regime may be considered as a constructive and beneficial contribution to the development of the Malaysian law. It must be reemphasised that, by following the footstep of the American in enacting promissory estoppel into their Article 90 of the Second Restatement of Contract, the positive effect of incorporating this equitable doctrine into the Malaysian statute law is twofold; firstly, it would help to clearly define the parameters of this doctrine, which would lead to more certainty in litigation and secondly, its statutory enactment would certainly facilitate its application by the Malaysian courts, which will no longer be bound by the restrictive rules of equity and the statutory restrictions imposed by Section 3(1) of the Civil Law Act 1956. The potential of enacting promissory estoppel into a statutory form would be able to facilitate its application. By incorporating this doctrine into the Malaysian statutory regime, promissory estoppel would be devoid of the three restrictions mentioned beforehand. Its parameters will be clearly defined beyond doubt and its application would no longer be subject to the provision of Section 3(1) of the Civil Law Act 1956.

In the end, it can be safely concluded that such incorporation will be able to greatly benefit the Malaysian legal fraternity by providing and leading to more certainty in litigation. Now that the trend in contract law is moving away from the older notion of contractual freedom towards contractual justice, the incorporation of promissory estoppels as a statutory provision would contribute hugely to the development of the Malaysian contract law.

\section{References}

Australian House of Representatives. Parliamentary Debates (Hansard), 3 November 1992.

Denning, A.T. The Closing Chapter (1982). London: Butterworths.

His Royal Highness Sultan Azlan Shah (1989.) Engineers and the Law: Recent Developments. A Public Lecture delivered on $31^{\text {st }}$ March 1989 (sponsored by the Institute of Engineers Malaysia).

Lord Coke in Co. Litt. 352a. Quoted in Jackson, David. Estoppel as a Sword. (1965) LQR 84.

Loughlan, Patricia. No right to the Remedy: An Analysis of Judicial Discretion in the Imposition of Equitable Remedies. (1989-1990) 17 Melb ULR 132.

Martin, Elizabeth. The Concise Dictionary of Law. 1986. London: Oxford.

Miller, Russel. (1996). Annotated Trade Practices Act. (17 ${ }^{\text {th }}$ Ed.). Sydney: LBC.

Seah, Weeliem. (2001). Unfulfilled Promissory Contractual Terms and Section 52 of the Australian Trade Practices Act. Retrieved from http://www.murdoch.edu.au/elaw (November 21, 2009).

Seddon, Nick. (2001). Promises Binding in the Absence of Consideration. Retrieved from http://uniserve.edu.au/law.

Teo, K.S., \& Khaw, L.T. (1991). Equity in Malaysian Land Law. $9^{\text {th }}$ Malaysian Law Conference, 1991 (Kuala Lumpur)

Vohrah, Beatrix \& Wu, M.A. (2000). The Commercial Law of Malaysia. $\left(2^{\text {nd }}\right.$ Ed.). Petaling Jaya: Longman.

Wan Izatul Asma. The Boustead Case: The Departure from the Traditional Parameters of the Equitable Doctrine of Promissory Estoppel. Current Law Journal, 3, pages i-xi, 2003. 